БIOXIMIЯ

BIOCHEMISTRY

https://doi.org/10.15407/dopovidi2021.04.110

UDC 616.12:575:577.112.856

M.D. Tronko, https://orcid.org/0000-0001-7421-0981

S.A. Cherviakova, https://orcid.org/0000-0002-6917-5736

V.V. Pushkarev, https://orcid.org/0000-0001-5940-5510

Y.B. Belchina, https://orcid.org/0000-0002-4289-8977

O.I. Kovzun, https://orcid.org/0000-0001-8164-7671

V.M. Pushkarev, https://orcid.org/0000-0003-0347-7771

L.K. Sokolova, https://orcid.org/0000-0003-0011-0106

V.P. Komisarenko Institute of Endocrinology and Metabolism of the NAMS of Ukraine, Kyiv E-mail: pushkarev.vm@gmail.com

\title{
Apolipoprotein A1 level in plasma of patients with diabetes and diabetic patients with COVID-19 as a possible marker of disease
}

Presented by Corresponding Member of the NAS of Ukraine M.D. Tronko

Increased levels of high-density lipoprotein cholesterol (HDL-C) and apolipoprotein A1 (ApoA1) in plasma is associated with a reduced risk of developing cardiovascular diseases (CVD). In addition to its potential cardioprotective function, HDL and ApoA1, the main HDL apolipoprotein, also have antidiabetic properties. The aim of the study was to determine the level of ApoA1 in the blood of patients $(n=81)$ with type 2 diabetes mellitus and COVID-19. ApoA1 was determined by enzyme-linked immunosorbent assay (ELISA) (Elabscience, USA). The measurements were performed at an optical density of $450 \mathrm{~nm}$. We showed that the level of ApoA1 in the blood of patients with type 2 diabetes and especially with COVID-19 was significantly lower than in the blood of healthy people. Blood ApoA1 levels did not show a further decrease in patients with both COVID-19 and diabetes compared with patients with COVID-19 without diabetes. Thus, the level of ApoA1 may be one of the promising markers of severe COVID-19.

Keywords: COVID-19, type 2 diabetes, apolipoprotein A1.

It has been found that increased levels of high-density lipoprotein cholesterol (HDL-C) and apolipoprotein A1 (ApoA1) in plasma are associated with a reduced risk of developing cardiovascular diseases (CVD). In addition to its potential cardioprotective function, HDL and ApoA1, the main HDL apolipoprotein, also have antidiabetic properties. Increases in the plasma HDL and ApoA1 levels improve the glycemic control in patients with type 2 diabetes mellitus by

Ци ту в ання: Tronko M.D., Cherviakova S.A., Pushkarev V.V., Belchina Y.V., Kovzun O.I., Pushkarev V.M., Sokolova L.K. Apolipoprotein A1 level in plasma of patients with diabetes and diabetic patients with COVID-19 as a possible marker of disease. Допов. Наи. акад. наук Укр. 2021. № 4. С. 110-113. https://doi.org/10.15407/ dopovidi2021.04.110 
Plasma ApoA1 level of patients with diabetes and COVID-19 (g/l): 1 - control $(n=7) ; 2$ - patients with type 2 diabetes mellitus $(n=60) ; 3$ - patients with diabetes and COVID-19 $(n=16)$; 4 - patients with COVID-19 $(n=5) . M \pm m .{ }^{*}$ - differences from control are significant, $P<0.0001 ;+-$ differences from group 2 are significant, $P<0.0001$

enhancing pancreatic $\beta$-cell function and increasing insulin sensitivity [1]. ApoA1 also stimulates glucose uptake in vivo into skeletal and cardiac muscles [2]. The ApoB/ ApoA1 ratio has been found to be associated with type 2 diabetes and has been proposed as a novel biomarker

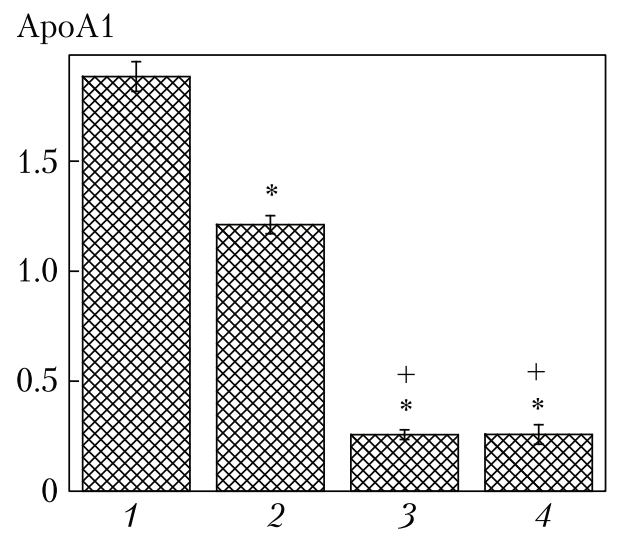
for its prediction [3]. Meta-analysis also shows that decreased ApoA1 levels and increased ApoB levels, as well as the ApoB/A1 ratio, are risk factors for the first ischemic stroke [4].

Materials and Methods. The study was conducted in the diabetology department of the Institute. The study protocol was approved by the Institute's ethics committee. All patients signed the informed consent to conduct further diagnostic and research studies.

Blood was obtained by standard venipuncture and stored in EDTA vacutainer tubes. Plasma was separated by centrifugation for $10 \mathrm{~min}$ after blood sampling. The samples were stored at $-80{ }^{\circ} \mathrm{C}$ until use. ApoA1 was determined $(n=81)$ using enzyme-linked immunosorbent assay (ELISA) kit (Elabscience, USA). The measurement was carried out at a 450-nm optical wavelength on an immunoenzymatic plate analyzer Stat Fax 3200 (Awareness Technology, USA).

Glycated hemoglobin was determined using one HbA1c FS kit (DiaSys Diagnostic Systems GmbH (Germany)). The measurement was carried out at a 660 -nm optical density.

Statistical analysis and data presentation were performed using the Origin 7.0 software. The results of the study are presented as $M \pm m$. To compare the data groups, the Student's $t$-test was used. Values of $P \leqslant 0.05$ were considered as significant.

Results and discussion. The blood plasma of 60 type 2 diabetes patients and 21 patients with diabetes and COVID-19 was used. As a control, we used the blood of healthy people $(n=7)$ without concomitant diseases, representative of age. The level of $\mathrm{Hb} 1 \mathrm{Ac}$ in diabetic patients was $9.62 \pm 0.27 ; \mathrm{BMI}-30.69 \pm 1.06 \mathrm{~kg} / \mathrm{m}^{2}$. The fasting glucose content in the blood of patients with COVID-19 and diabetes was $9.6 \pm 0.92 \mathrm{mmol} / \mathrm{l}$, at the time of discharge $-6.72 \pm 0.62 \mathrm{mmol} / \mathrm{l}$. Average $\mathrm{O}_{2}$ saturation was $87.3 \pm 0.7 \%$, which indicates a severe course of the disease.

It can be seen in Fig. that the average level of ApoA1 in the blood of healthy people is in the upper normal range $(1.88 \mathrm{~g} / \mathrm{l})$. In diabetic patients, this indicator is significantly lower $1.21 \mathrm{~g} / \mathrm{l}$ - closer to the lower limit of the norm. In patients with diabetes and COVID-19, the content of ApoA1 in blood is approximately $0.25 \mathrm{~g} / \mathrm{l}$, which is more than 4 times lower than normal values. It is of interest that there are no differences between patients with COVID-19 and diabetes and patients with only COVID-19 (Fig.). In the blood of some patients with COVID-19, the level of ApoA1 decreased to almost zero values - $0.09 \mathrm{~g} / \mathrm{l}$.

The fact that the level of ApoA1 in blood does not decrease in patients with COVID-19 and diabetes compared to patients without diabetes, indicates that COVID-19 creates a complex of significantly more powerful factors affecting the content of ApoA1, and such a decrease reaches a lower limit. 
A decrease in the level of ApoA1 in the blood of diabetic patients and an increase in the risk of CVD were noted in many studies [5-8].

It was also pointed out that ApoA1 was identified as the seed of the protein complex, and APP (Amyloid beta A4 protein), EGF (epidermal growth factor), and complement C3 were the main bottlenecks in the network. ApoA1 carries anti-inflammatory properties that could assist in the regulation of the immune response. The obtained data indicate that upregulation of $\mathrm{C} 3$ and downregulation of ApoA1 in urine affect respiratory rigidity and, thus, the severity of COVID-19. Moreover, dysregulation of APP and ApoA1 may contribute to the possible side effects of COVID-19 on the nervous system [9,10].

Conclusions. The level of ApoA1 in the blood of patients with diabetes and especially COVID-19 was significantly lower then in blood of healthy people.

The level of ApoA1 may be one of the promising markers of COVID-19.

\section{REFERENCES}

1. Rye, K. -A., Barter, P. J. \& Cochran, B. J. (2016). Apolipoprotein A-I interactions with insulin secretion and production. Curr. Opin. Lipidol., 27, No. 1, pp. 8-13. https://doi.org/10.1097/MOL.0000000000000253

2. Fritzen, A. M., Domingo-Espín, J., Lundsgaard, A. M., Kleinert, M., Israelsen, I., Carl, C. S., Nicolaisen, T. S., Kjøbsted, R., Jeppesen, J. F., Wojtaszewski, J. F. P., Lagerstedt, J. O. \& Kiens, B. (2020). ApoA-1 improves glucose tolerance by increasing glucose uptake into heart and skeletal muscle independently of AMPK $\alpha_{2}$. Mol. Metab., 35, 100949. https://doi.org/10.1016/j.molmet.2020.01.013

3. Mao, Y., Xu, Y. \& Lu, L. (2017). The nonlinear association between apolipoprotein B to apolipoprotein A1 ratio and type 2 diabetes. Medicine (Baltimore). 96, No. 1, e5834. https://doi.org/10.1097/ MD.0000000000005834. Erratum in: Medicine (Baltimore), 96, No. 12, e6541. Erratum in: Medicine (Baltimore), 96, No. 17, e6821.

4. Dong, H., Chen, W., Wang, X., Pi, F., Wu, Y., Pang, S., Xie, Y., Xia, F. \& Zhang, Q. (2015). Apolipoprotein A1, $\mathrm{B}$ levels, and their ratio and the risk of a first stroke: a meta-analysis and case-control study. Metab. Brain Dis., 30, No. 6, pp. 1319-1330. https://doi.org/10.1007/s11011-015-9732-7

5. Sokolova, L. K. (2014). Risk factors and clinical and diagnostic aspects of cardiovascular pathology in patients with type 1 and 2 diabetes mellitus. (Extended abstract of Doctor thesis). V.P. Komisarenko State Institute of Endocrinology and Metabolism of the National Academy of Medical Sciences of Ukraine, Kyiv, Ukraine (in Ukrainian).

6. Cochran, B. J., Ong, K. -L., Manandhar, B. \& Rye, K. -A. (2021). High density lipoproteins and diabetes. Cells, 10, No. 4, 850. https://doi.org/10.3390/cells10040850

7. Gao, L., Zhang, Y., Wang, X. \& Dong, H. (2021). Association of apolipoproteins A1 and B with type 2 diabetes and fasting blood glucose: a cross-sectional study. BMC Endocr. Disord., 21, No. 1, 59. https://doi. org/10.1186/s12902-021-00726-5

8. Retnakaran, R., Ye, C., Connelly, P. W., Hanley, A. J., Sermer, M. \& Zinman, B. (2019). Serum apoA1 (apolipoprotein A-1), insulin resistance, and the risk of gestational diabetes mellitus in human pregnancy - brief report. Arterioscler. Thromb. Vasc. Biol., 39, No. 10, pp. 2192-2197. https://doi.org/10.1161/ATVBAHA.119.313195

9. Yang, Y., Zhu, Z., Fan, L., Ye, S., Lou, K., Hua, X., Huang, Z., Shi, Q. \& Gao, G. (2020). Low serum level of apolipoprotein A1 is an indicator of severity in patients with coronavirus disease 2019. Preprint. https://doi. org/10.21203/rs.3.rs-33301/v1

10. Zamanian Azodi, M., Arjmand, B., Zali, A. \& Razzaghi, M. (2020). Introducing APOA1 as a key protein in COVID-19 infection: a bioinformatics approach. Gastroenterol. Hepatol. Bed Bench., 13, No. 4, pp. 367-373. https://doi.org/10.22037/ghfbb.v13i4.2111

Received 02.06.2021 
М.Д. Тронько, https://orcid.org/0000-0001-7421-0981

С.А. Червякова, https://orcid.org/0000-0002-6917-5736

В.В. Пушкарьов, https://orcid.org/0000-0001-5940-5510

Ю.Б. Бельчина, https://orcid.org/0000-0002-4289-8977

O.I. Ковзун, https://orcid.org/0000-0001-8164-7671

В.М. Пушкарьов, https://orcid.org/0000-0003-0347-7771

Л.К. Соколова, https://orcid.org/0000-0003-0011-0106

ДУ “Інститут ендокринології та обміну речовин ім. В.П. Комісаренка НАМН України”

E-mail: pushkarev.vm@gmail.com

\section{РІВЕНЬ АПОЛІПОПРОТЕЇНУ А1 У ПЛАЗМІ КРОВІ ХВОРИХ}

НА ЦУКРОВИЙ ДІАБЕТ ТА ХВОРИХ НА ЦУКРОВИЙ ДІАБЕТ IЗ COVID-19 ЯК МОЖЛИВИЙ МАРКЕР ЗАХВОРЮВАННЯ

Підвищений рівень холестерину ліпопротеїнів високої щільності (ЛПВЩ-Х) та аполіпопротеїну А1 (АроА1) у плазмі асоціюється із зниженим ризиком розвитку серцево-судинних захворювань. Окрім потенційної кардіопротекторної функції, ЛПВЩ та АпоА1, основний аполіпопротеїн ЛПВЩ, також мають протидіабетичні властивості. Визначено рівень АроА1 у крові хворих $(n=81)$ на цукровий діабет 2-го типу та COVID-19. АроA1 визначали за допомогою набору для імуноферментного аналізу (ELISA) (Elabscience, США). Вимірювання проводили при оптичній довжині хвилі 450 нм. Показано, що рівень АроA1 у крові хворих на цукровий діабет 2-го типу і, особливо, з COVID-19 був значно нижчим, ніж у крові здорових людей. Рівень АроА1 у крові не демонструє подальшого зниження у пацієнтів як з COVID-19, так i 3 діабетом порівняно з хворими на COVID-19 без діабету. Рівень АроA1 може бути одним із перспективних маркерів тяжкого перебігу COVID-19.

Ключові слова: COVID-19, діабет 2-го типу, аполіпопротеїн A1. 